
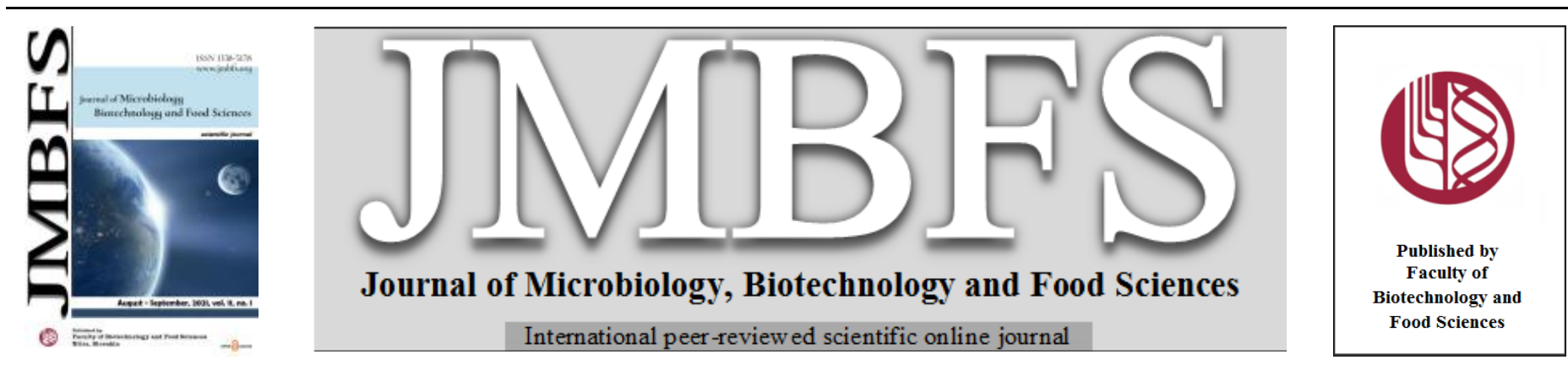

\title{
PRODUCTION, PURIFICATION AND CHARACTERIZATION OF AN ANTIBACTERIAL COMPOUND FROM STREPTOMYCES GRISEUS TBG19NRA1 ISOLATED FROM THE FOREST SOILS OF THE WESTERN GHATS OF KERALA, INDIA
}

\section{Shiburaj Sugathan*, Gayathri Valsala and Jeeshma Nambidi Parambath}

Address(es): Dr. Shiburaj Sugathan,

Jawaharlal Nehru Tropical Botanic Garden and Research Institute, Palode, Thiruvananthapuram, Kerala, India, Pin-695 562, Ph. No. +919495826669.

*Corresponding author: drshiburaj@gmail.com

https://doi.org/10.15414/jmbfs.590

\section{ARTICLE INFO}

Received 7. 8. 2018

Revised 28. 3. 2020

Accepted 3. 3. 2021

Published 1. 8. 2021

Regular article

open $\mathcal{O}$ access

\section{ABSTRACT}

A new actinomycete strain designated TBG19NRA1, exhibiting antimicrobial activities against Gram-positive and Gram-negative bacteria, was isolated from forest soil of Neyyar Wild Life Sanctuary, Thiruvananthapuram, Kerala. Cultural characteristics strongly suggested that this isolate belongs to the genus Streptomyces. Polyphasic taxonomic studies including phylogenetic analysis based on $16 \mathrm{~S}$ rDNA sequence suggests that the isolate is a strain of S. griseus. Studies on the effect of different nutritional compounds on antibiotic activity revealed that the highest antibacterial activity was obtained when $1 \%$ starch (w/v) was used as the sole carbon source along with mineral trace elements. Extraction and purification of TBG19NRA1 culture supernatant led to the isolation of a pure molecule with good antibacterial activity. The compound has been identified as the cyclic polyether lasalocid A on the basis IR, MS and ${ }^{13} \mathrm{C}$ NMR data interpretation and comparison with reference data from literature.

Keywords: Actinomycetes; antimicrobial activities; Streptomyces griseus; 16s rDNA; lasalocid

\section{INTRODUCTION}

The actinomycetes form an important part of the microbial community inhabiting many natural environments, and are responsible for various geochemical cycles. The actinomycete genus Streptomyces is an industrially important group as the members of this group produce a wide array of bioactive molecules ranging from antibiotics, enzymes, enzyme inhibitors, inducers of eukaryotic cellular differentiation, inducers and inhibitors of apoptosis, protein kinase inhibitors with antitumor activity and other pharmacologically active agents (Jeong et al., 2010; Olano et al., 2009; Yoshimoto et al., 2000)). Indeed, actinomycetes produce two-thirds of the known antibiotics that are produced by microorganisms; of these about $80 \%$ are made by the members of the genus Streptomyces (Kieser $\boldsymbol{e}$ al., 2000; Lucas et al., 2013). The fast emerging threat of bacterial resistance to the existing antibiotics demands the search for novel antibacterial metabolites, and several research studies are currently oriented towards the isolation of new Streptomyces species from exotic environmental samples (Fair and Tor, 2014).

The genus Streptomyces contains aerobic spore forming actinomycetes which have a high guanine-plus-cytosine $(\mathrm{G}+\mathrm{C}$ mol \%) containing genomic DNA. They differentiate to produce branching substrate and aerial mycelia with long conidial chains. Several taxonomic tools have so far been used to classify Streptomyces species, which include culturing and physiological methods, chemo-taxonomic and numerical taxonomic tools and their combinations (Anderson and Wellington, 2001). Application of genotypic approach to Streptomyces classification has contributed considerably to the extension of our knowledge of the phylogenetic relationships between strains of this genus. Of the several genetic approaches, 16S rDNA sequence analysis has proven to be a powerful tool in Streptomyces taxonomy (Patel et al., 2004).

Antibiotic biosynthesis is a characteristic of certain microorganisms, and this property is often influenced by primary metabolism. Optimization of nutrient conditions is necessary for the maximum accumulation of antibiotic compounds, since the intermediate metabolites from primary metabolisms serves as precursors for the biosynthesis of antibiotics (Mellouli et al. 2003). Isolation and characterization of active secondary metabolites from fermented broth involve several steps like solvent extraction, precipitation, chromatography and spectroscopic analysis.

In the present study, we describe the isolation of a new Streptomyces strain TBG19NRA1 from the forest soil of Neyyar wild life sanctuary, South India, producing antibacterial activity. Identification of this strain using polyphasic approach as well as the study of the influence of different nutritional compounds on antibiotic biosynthesis is reported. The extraction, purification and structure elucidation of the active molecule from the strain TBG19NRA1 is carried out and its biological activity is described.

\section{MATERIAL AND METHODS}

\section{Microorganisms Used}

The strain TBG19NRA1, isolated from forest soil of Neyyar Wild Life Sanctuary, Trivandrum, Kerala was analyzed for the production of potent antimicrobial molecules. The microorganisms used for antimicrobial assays were Escherichia coli (MTCC 739), Staphylococcus aureus (MTCC 740) and Candida albicans (MTCC 221). They were procured from Microbial Type Culture collection and gene bank (MTCC), Institute of Microbial Technology (IMTECH), Chandigarh, India. The minimum inhibitory concentration (MIC) of the purified antibiotic was determined against above strains as well as other bacterial strains like Arthrobacter protophormiae (MTCC 2682), Bacillus cereus (MTCC 430), B. subtilis (MTCC 441), E. coli (MTCC 443), Klebsiella pneumoniae subsp. pneumoniae (MTCC 109), Proteus vulgaris (MTCC 426), Pseudomonas fluorescens (MTCC 103), P. aeruginosa (MTCC 741), Salmonella typhi (MTCC 733), S. aureus subsp. aureus (MTCC 737) and yeast strain Saccharomyces cerevisiae (MTCC 36).

\section{Culture Conditions}

For antimicrobial assay, an inoculum of Steptomyces TBG19NRA1 was prepared in $20 \mathrm{ml}$ Tryptone-Yeast extract broth (ISP-1 media) in $100 \mathrm{ml}$ Erlenmeyer flasks and inoculated to $100 \mathrm{ml}$ Antibiotic Sensitivity broth containing $1.5 \%$ glucose, $1 \%$ calcium carbonate, $1.5 \%$ soya meal, $0.25 \%$ glycerol, $0.5 \% \mathrm{NaCl}$ and $0.1 \%$ yeast extract (Atlus and Perks, 1993) in $250 \mathrm{ml}$ Erlenmeyer flasks. The flasks were incubated at room temperature $\left(28+1{ }^{\circ} \mathrm{C}\right)$ on a rotary shaker at 120 rpm for 5 days. The test bacterial strains were grown overnight in LB broth at $37^{\circ} \mathrm{C}$, while the Candida strain was grown overnight in Sabouraud's Dextrose Broth (SDB) at $30^{\circ} \mathrm{C}$, to be used as inoculum for antimicrobial assays.

To investigate the influence of culture medium on antibiotics production, spores at $10^{7} / \mathrm{ml}$ were used to inoculate $500 \mathrm{ml}$ Erlenmeyer flasks containing $200 \mathrm{~mL}$ each Antibiotic Sensitivity broth (without glucose), each supplemented with one of the five carbon sources (starch, fructose, galactose, lactose, sucrose) in $1 \%$ $(\mathrm{w} / \mathrm{v})$ concentration. Each culture was done in triplicate. After incubation at $28+$ 
$1{ }^{\circ} \mathrm{C}$ for $120 \mathrm{~h}$ in an orbital incubator with shaking at $200 \mathrm{rpm}$, antibacterial activities were assayed for each culture supernatant. After determination of the best carbon source, the influence of varying concentrations of trace mineral oligoelements and phosphate on antibiotic production was investigated under the same culture conditions described above. Pridham and Gottilieb trace salt solution (Shirling and Gottlieb, 1966) containing $\mathrm{CuSO}_{4} .5 \mathrm{H}_{2} \mathrm{O}(6.4 \mathrm{mg} / \mathrm{ml})$ $\mathrm{FeSO}_{4} \cdot 7 \mathrm{H}_{2} \mathrm{O}(1.1 \mathrm{mg} / \mathrm{ml}), \mathrm{MnCl}_{2} .4 \mathrm{H}_{2} \mathrm{O}(7.9 \mathrm{mg} / \mathrm{ml})$ and $\mathrm{ZnSO}_{4} .7 \mathrm{H}_{2} \mathrm{O}$ $\mathrm{mg} / \mathrm{ml})$ was used at 0.02 to $0.2 \%(\mathrm{v} / \mathrm{v})$ and Phosphate $\left(\mathrm{K}_{2} \mathrm{HPO}_{4}\right)$ at 0.05 to $0.4 \%$ $(\mathrm{w} / \mathrm{v})$ in the liquid culture medium

Cultural characteristics of strain TBG19NRA1 were observed after 7, 14 and 21 days of incubation on nutrient agar, Sabouraud's Dextrose Agar (SDA), Yeas Malt Agar media and on different ISP media as per ISP methods (Shirling and Gottlieb, 1966). Cell mass for all chemotaxonomic tests was obtained by growing cultures in shake flasks for 5 days at $30^{\circ} \mathrm{C}$ in Yeast Extract Malt Extract broth (ISP-2), followed by freeze-drying.

\section{Microscopy, Physiology and Biochemistry of study organism}

Micro-morphology and sporulation were determined by phase contras microscopy (Nikon Optiphot-II) and scanning electron microscopy (Hitachi S2400). The samples used for scanning electron microscopy were from 14-day slide cultures prepared on ISP-2 media that had been fixed with modified Karnovsky's fixative and followed by $1 \mathrm{~h}$ in $1 \%$ osmium tetroxide, dehydrated through a graded acetone series, critical point dried from liquid $\mathrm{CO}_{2}$, and sputter coated with gold-palladium (Chakrbarti, 1998).

Standard physiological tests were performed after growth at $30^{\circ} \mathrm{C}$ (unless otherwise stated) for the recommended incubation periods as described (Williams and Sharpe, 1989). Antibiotic resistance was determined by addition of the antibiotics into Bennett's Medium agar plates at the recommended concentrations (Williams and Sharpe, 1989). All carbon sources for carbonutilization tests were ether sterilized and tested at the concentrations and conditions recommended by ISP (Shirling and Gottlieb, 1966). The cell wall Diaminopimelic acid (DAP) analysis was carried out by TLC method (Staneck and Roberts, 1974)

\section{DNA isolation and 16S rDNA sequence analysis}

Total DNA preparation from strain TBG19NRA1 was carried out according to Murray and Thompson (Murray and Thompson, 1980). The base composition $(\mathrm{G}+\mathrm{C}$ mol \%) was determined in $0.1 \mathrm{M}$ standard saline citrate (SSC) by the method of Mandel and Marmur (1968).

PCR amplification of approximately $1.5 \mathrm{~kb}$ of $16 \mathrm{~S}$ ribosomal DNA (rDNA) of TBG19NRA1 was performed using the eubacterial primers 8-27F, 5, AGAGTTTGATCCTGGCTCAG 3' (Escherichia coli positions 8 to 27), and 1495R 5'-CTACGGCTACCTTGTTACGA -3' (E. coli positions 1495 to 1476) were modified from primers fD1 and rP2, respectively, of Weisburg et al (1991). Amplification of the 16S rRNA was performed using a BioRad S1000 Thermal Cycler, with a reaction mix composed of 30-50 ng template DNA, 0.4 $\mu \mathrm{M}$ each of both primers, $12.5 \mu 1$ EmeraldAmp GT PCR Master Mix (Takara Bio Inc, Japan) in a final volume of $25 \mu \mathrm{l}$. PCR was performed under the following conditions: $1 \mathrm{~min}$ at $98^{\circ} \mathrm{C}$, followed by 35 cycles of $10 \mathrm{sec}$ at $98^{\circ} \mathrm{C}, 30 \mathrm{sec}$ at $58^{\circ} \mathrm{C}, 1.5 \mathrm{~min}$ at $72^{\circ} \mathrm{C}$ and a final extension of $72^{\circ} \mathrm{C}$ for $10 \mathrm{~min}$. The amplified PCR product was analyzed by agarose gel electrophoresis and the DNA of the expected size was purified by electro-elution.

The purified PCR amplified 16S rRNA gene was sequenced using the dideoxy chain-termination method (Sanger et al., 1977) at Scigenom Labs, Cochin, Kerala, India. Sequencing was done using an ABI Prism 310 Genetic Analyzer (Applied Biosystems) using the amplification primers (8-27F and1495R) and two internal primers 338F, 5'-ACTCCTACGGGAGGCAGC-3'; 798R, 5' AGGGTATCTAATCCT-3', hybridizing respectively at positions 338-355 and 798-784, according to the E. coli 16 s rRNA numbering. The sequences obtained were aligned using Contig Assembly Program of BioEdit software, to obtain almost complete (1495 bp) $16 \mathrm{~S}$ rDNA gene sequence, which was submitted to GenBank with accession number KX269853. The obtained rDNA sequence was used for homology search using BLAST search algorithm and similar sequences retrieved from GenBank were aligned using ClustalW tool of BioEdit (Thompson et al., 1997). The MEGAX software was used for the construction of a phylogenetic tree using the ClustalW aligned sequences (Kumar et al., 2018) and the evolutionary history was inferred using the Neighbor-Joining method (Saitou and Nei, 1987). Computation of evolutionary distances was carried out using the Jukes-Cantor method (Jukes and Cantor, 1969), and is in the units of number of base substitutions per site. A bootstrap confidence analysis was performed for 1000 replicates to determine the reliability of the distance tree topologies obtained (Felsenstein, 1985).

\section{Biological assay of antimicrobial activities}

The culture filtrates collected from 5 days old culture in Antibiotic Sensitivity broth (Atlus and Perks, 1993) were analysed for antimicrobial activity following Agar-Cup-Plate method and disc diffusion method against selected bacterial strains and Candida albicans. Seventy five micro-litres of different culture filtrates of TBG19NRA1 were applied to the $5 \mathrm{~mm}$ diameter wells on agar plates spread with test organisms. Whatman paper discs (No.3) of $5 \mathrm{~mm}$ diameter impregnated with purified antibiotic compound of different dilutions were used for determination of MIC values. Plates were incubated at $37^{\circ} \mathrm{C}$ for overnight growth of bacteria and at $30^{\circ} \mathrm{C}$ for $24 \mathrm{~h}$ for Candida. Plates were examined for antimicrobial activities, represented by a zone of inhibition of bacterial/fungal growth around the well or the paper disk.

\section{Extraction, purification and spectroscopic analysis of active compound}

TBG19NRA1 cultured at $28+1{ }^{0} \mathrm{C}$ for $120 \mathrm{~h}$ was harvested to remove the biomass, and the cell-free supernatant was mixed with equal volume of $n$-butanol and shaken vigorously at room temperature for $2 \mathrm{~h}$ in a separating funnel. The butanol layer was checked for antibiotic activity and concentrated in vacuo. This was further extracted with ethyl acetate $(250 \mathrm{ml} \mathrm{x} \mathrm{3)}$ and the ethyl acetate phase evaporated in vacuo and the residue was dissolved in $5 \mathrm{ml}$ chloroform. The chloroform fraction was passed through a silica gel (60 120 mesh) column. Solvent systems of chloroform-methanol (99.5:0.5), followed by chloroformmethanol (9:1) was used for fractionation. Fractions of $10 \mathrm{ml}$ each were collected and checked for antimicrobial activity by disc diffusion method. The active fractions were concentrated under reduced pressure. The resultant oily residue was dissolved in $20 \mathrm{ml}$ diethyl ether and filtered. Filtrate was evaporated in room temperature to form an amorphous solid, which was crystallized by adding absolute ethanol.

Silica gel thin layer chromatography (TLC) using solvent system benzene:methanol (19:1) showed single spot under ultraviolet light (365nm).

Melting point was determined by capillary method and is uncorrected. UV spectrum was measured on a Shimadzu UV-2100 spectrophotometer using methanol as solvent. IR spectrum was recorded on a Bruker IFS 66V FT- IR spectrophotometer following $\mathrm{KBr}$ pellet method. ${ }^{13} \mathrm{C}$ NMR spectra $(75 \mathrm{MHz})$ was taken using Jeol GSX NB $400 \mathrm{MHz}$ NMR spectrophotometer with TMS as internal standard. Mass spectra was taken on a Finnigan MAT 8230 mass spectrometer.

\section{RESULTS AND DISCUSSION}

\section{Isolation and characterization of strain TBG19NRA1}

The actinomycete strain TBG19NRA1 isolated from the forest soil of Neyyar Wild Life Sanctury of South India exhibited antimicrobial activities against Gram-positive and Gram-negative bacteria and fungi. Permissive temperature range for growth of the strain TBG19NRA1 was 10 to $36^{\circ} \mathrm{C}$, with $30^{\circ} \mathrm{C}$ and $\mathrm{pH}$ 6.5 as optimum conditions. According to cultural characteristics (Table 1), strain TBG19NRA1 grew well with elevated and spreading colonies. The colours of the aerial and vegetative mycelia were white to light grey and yellowish brown respectively. The vegetative hyphae produced branched mycelia that rarely fragmented. Aerial mycelia forms well developed Rectus-flexibilis type spore chains bearing more than 20 spores of size $0.86-1.03 \times 0.6 \mu \mathrm{m}$ (Fig.1A). Electron micrograph of the aerial mycelia shows that the spore surface is smooth and without any ornamentation (Fig.1B). The cell wall peptidoglycan of the organism contains LL-diaminopimelic acid. The isolate did not produce melanin or other soluble pigments. The isolate shows resistance to the antibiotics like penicillin $\mathrm{G}$ and rifampicin. The strain was found to utilize carbon sources like dextran, D fructose, D-galactose, D-lactose, mannitol, D-mannose, L-ramnose and trehalose. The $\mathrm{G}+\mathrm{C}$ content of DNA was $73.44 \mathrm{~mol} \%$.

The morphological and chemotaxonomic characteristics of strain TBG19NRA1 were compared with those of the known species of actinomycetes described in Bergey's manual of systematic bacteriology (Williams and Sharpe, 1989). The culture characteristics strongly suggest that strain TBG19NRA1 belongs to the genus Streptomyces. Taxonomic characterization of strain TBG19NRA1 with ISP strains according to the classification key of Nonomura (Nonomura, 1974) and the ISP descriptions (Shirling and Gottlieb, 1969) revealed the isolate to be closely related to Streptomyces setonii, which was now considered as heterotypic synonym of $S$. griseus (Liu et al., 2005).

In order to confirm the identification, 16S rRNA gene of TBG19NRA1 strain was amplified using primers designed based on the conserved regions of eubacterial 16s rDNA (Weisburg et al., 1991) and sequenced. The almost complete 16S rDNA sequence of 1495 bp (NCBI accession number KX269853) was compared with those of similar sequences deposited in public databases. Analysis of this sequence shows high similarity to $S$. griseus $16 \mathrm{~S}$ rRNA genes. A phylogenetic analysis, of this strain and 23 reference strains whose sequences were available, is shown in Fig. 2. In the phylogenetic tree, the strain TBG19NRA1 clusters with $S$. griseus and allied species. Based on genotypic and phenotypic characters, the strain was identified as Streptomyces griseus (Millard \& Burr, 1926; Waksman, 1953) and deposited in Microbial Type Culture Collection and Gene Bank, Chandigarh, India with an accession number MTCC 3756. 
Table 1 Cultural characters of TBG19NRA1 strain on Different growth media Cultural characteristics

\begin{tabular}{lcccc}
\cline { 3 - 5 } Medium & Growth & $\begin{array}{c}\text { Substrate } \\
\text { mycelium }\end{array}$ & $\begin{array}{c}\text { Aerial } \\
\text { mycelium } \\
\text { (Growth \& } \\
\text { Colour) }\end{array}$ & $\begin{array}{c}\text { Soluble } \\
\text { pigments }\end{array}$ \\
\hline ISP 2 & Yellow & Grown & Good, White & None \\
ISP 3 & Good & Yellow & Good, & None \\
ISP 4 & Good & Yellown & White/grey & Good, White \\
ISP 5 & Good & Brown & Good, & Good, White \\
SDA & Good & Yellow & Good, & None \\
Nutrient agar & Poor & Yellown & White/grey & - \\
& & Brown & - &
\end{tabular}

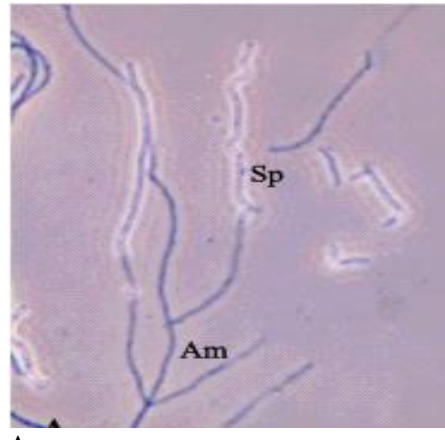

A

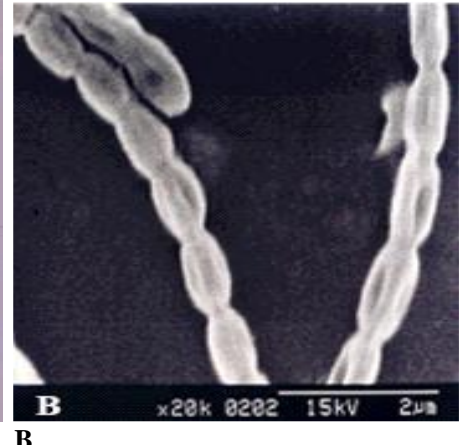

Figure 1 Microphotographs showing the morphology of TBG19NRA1

A: Phase contrast microphotograph (Nikon Optiphot-II) of strain TBG19NRA1 taken after 14 days of growth on ISP-2 media as slide cultures, showing aeria mycelium (Am) and Rectus-flexibilis type spore chain (Sp). B: Scanning Electron microphotograph of strain TBG19NRA1. The strain was grown for 14 days as slide cultures prepared on ISP-2 media and was fixed with modified Karnovsky's fixative and $1 \%$ osmium tetroxide, dehydrated through a graded acetone series, critical point dried using liquid $\mathrm{CO}_{2}$, and sputter coated with goldpalladium. The scanning electron microphotograph (Hitachi S-2400) showing spore chain with smooth walled spores (scale $4 \mathrm{~cm}=2 \mu \mathrm{m}$ ).

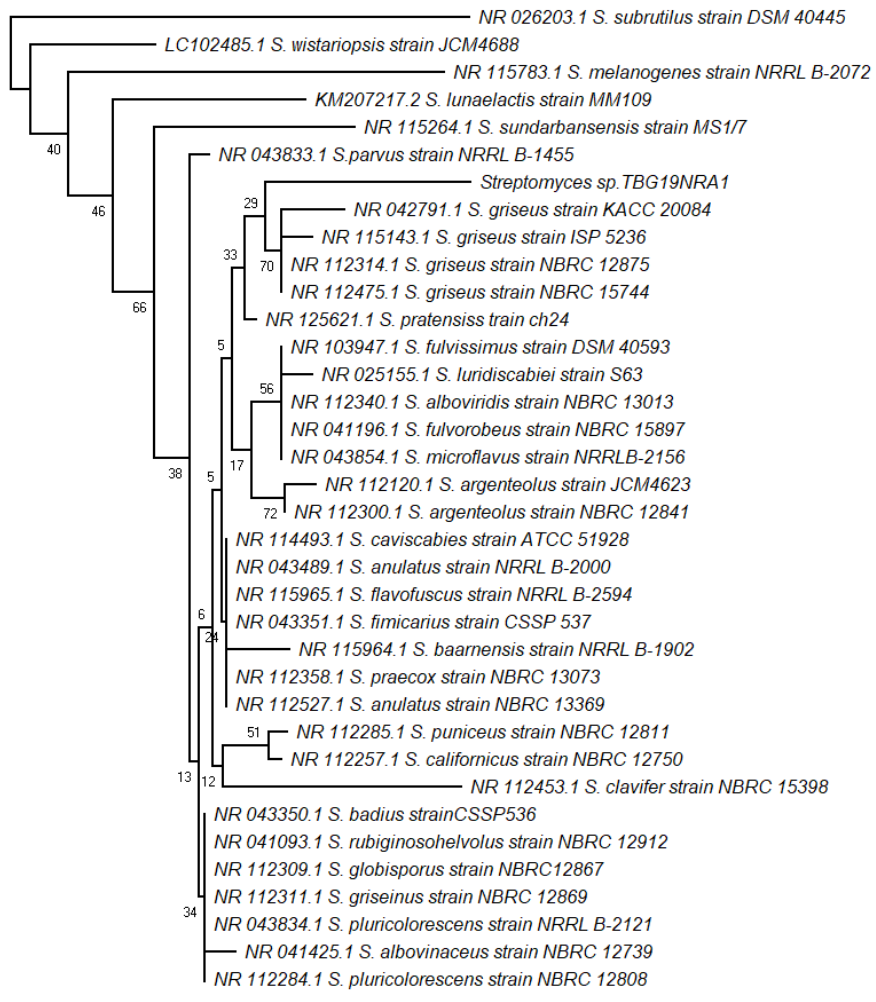

0.0020

Figure 2 Phylogenetic tree constructed from a multiple sequence alignment of the $16 \mathrm{~S}$ rRNA of Streptomyces spp.
The evolutionary history was inferred using the Neighbor-Joining method. The optimal tree with the sum of branch length $=0.05719313$ is shown. The percentage of replicate trees in which the associated taxa clustered together in the bootstrap test (1000 replicates) are shown next to the branches. The tree is drawn to scale, with branch lengths in the same units as those of the evolutionary distances used to infer the phylogenetic tree. The evolutionary distances were computed using the Jukes-Cantor method and are in the units of the number of base substitutions per site. The analysis involved 36 nucleotide sequences. All positions containing gaps and missing data were eliminated. There were a total of 1407 positions in the final dataset. Evolutionary analyses were conducted in MEGA X.

Optimization of culture conditions and quantification of antimicrobial activities in liquid media

To investigate the effect of various carbon sources on antibiotic biosynthesis by $S$. griseus TBG19NRA1 strain, different carbohydrates (Starch, Fructose, Galactose, Lactose, and Sucrose) were tested as sole carbon source at $1 \%(\mathrm{w} / \mathrm{v})$ concentration in antibiotic assay broth (Atlus and Perks, 1993). After incubation at $28+1^{\circ} \mathrm{C}$ as described earlier, antibacterial activities were assayed for each culture supernatant using the bioassay test against indicator test bacteria (E. coli MTCC 739, S. aureus MTCC 740) and C. albicans (MTCC 227). An increase in antibiotic production was observed only when starch was used as carbon source and the antibiotic produced was found to have antimicrobial activity against the three indicator microorganisms (Fig. 3). In order to further optimize the culture conditions, we studied the influence of Phosphorus and trace mineral elements at different concentrations. After $120 \mathrm{~h}$ incubation in the same conditions described above, it was found that inorganic phosphate $\left(\mathrm{K}_{2} \mathrm{HPO}_{4}\right)$ inhibited antibiotic production (Fig. 3). It should be noted that the haloes of inhibition of indicator microorganism growth were higher in starch plus $0.06 \%(\mathrm{v} / \mathrm{v})$ of trace element solution grown culture than in starch only. According to these results, antibiotic production by this isolate was negatively affected by fructose, galactose, lactose, sucrose and phosphate, whereas starch and trace mineral elements (up to $0.06 \%$ ) increased antibiotic yield. It has been shown that the nature of carbon and nitrogen sources, phosphorus, potassium, magnesium and trace mineral oligoelements, strongly affects antibiotic production in different organisms in different ways (Holmalahti et al., 1998).
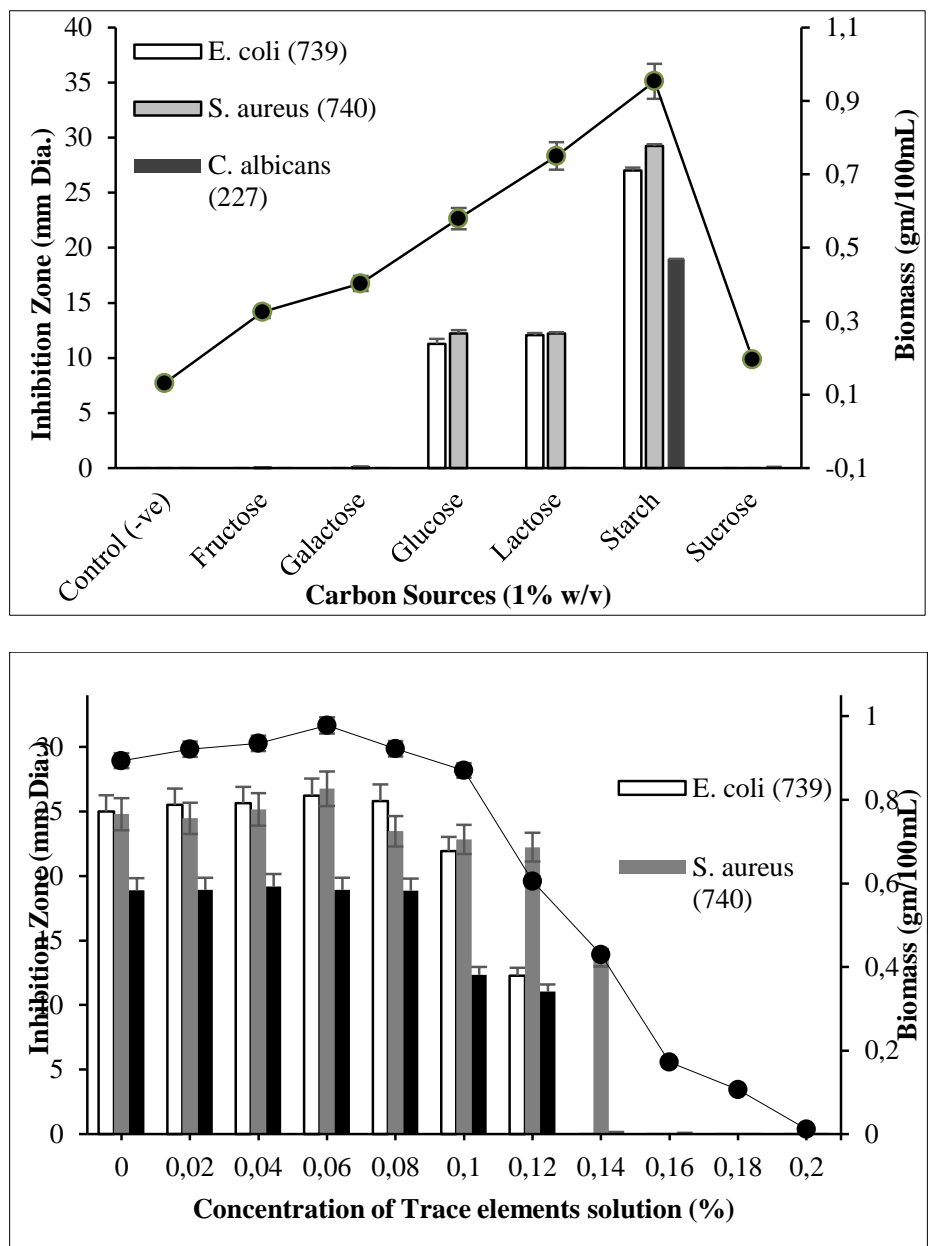


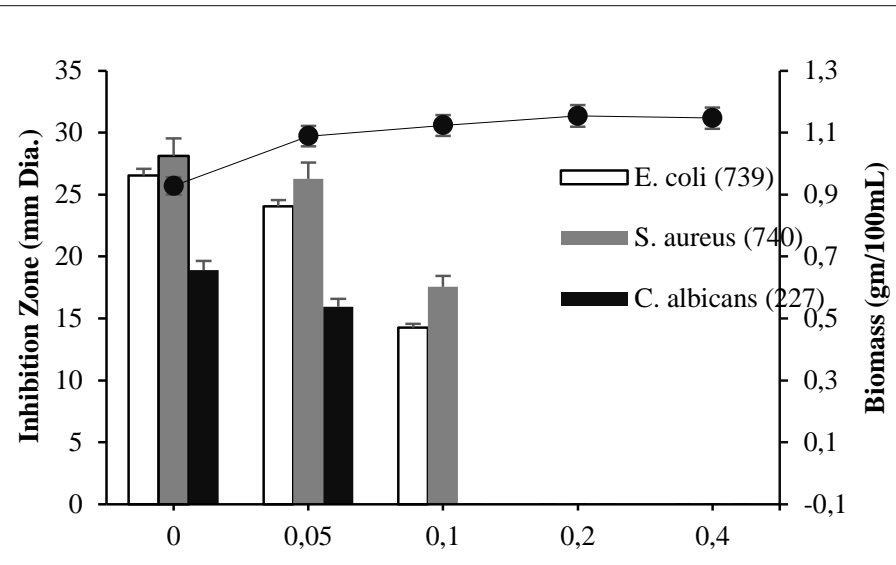

Inorganic Phosphate (KH2PO4) Concentration (\%)

Figure 3 Effect of different nutrient conditions on antibiotic accumulation and growth

The indicator organisms used were E. coli (MTCC 739), S. aureus (MTCC 740) and $C$. albicans (MTCC 227). Cell free culture filtrates $(75 \mu 1)$ of strain TBG19NRA1 were used for bio-activity assay following Agar-Cup-Plate (5mm) method.

\section{Isolation, purification and spectroscopic analysis of the active compound}

Cell-free supernatant of one litre shake flask culture of the Streptomyces sp. TBG19NRA1 grown in antibiotic assay medium in the presence of $1 \%(\mathrm{w} / \mathrm{v})$ starch and $0.06 \%(\mathrm{v} / \mathrm{v})$ of trace mineral salt solution was used for the isolation of the antibiotic as described under materials and methods. The purified antibiotic compound TBGA-1 is a white amorphous powder with melting point $132-135^{\circ} \mathrm{C}$ The compound is readily soluble in many of the organic solvent but insoluble or sparingly in ethanol and water.

The compound has been identified as lasalocid A (Fig. 4) based on comparison of the spectral data of the compound with the published data for lasalocid A. The results of spectral analysis are given as supplementary data. The Thin Layer Chromatography (TLC) of the compound on pre-coated Silica gel $60 \mathrm{~F}_{254}$ plate (Merck) using the solvent system benzene: methanol (19:1) gave single spot ( $R$ value 0.44 ). The compound gave positive colour test with $\mathrm{FeCl}_{3}$, indicating phenolic nature. The ultraviolet spectrum in methanol (Fig.S1) exhibited absorption maxima at $315 \mathrm{~nm}(\varepsilon$ 2865) and $250 \mathrm{~nm}$ ( $\varepsilon$ 2800) indicating the presence of aromatic ring, substituted with a hydroxyl and carboxyl group (Berger et al., 1951, Patel and Shen, 1976). Infrared spectrum of the compound (Fig. S2) indicated the presence of two carbonyl absorptions at $1710 \mathrm{~cm}^{-1}$ (aromatic $\mathrm{COO}^{-}$) and $1651 \mathrm{~cm}^{-1}$ (ketone), and a broad hydroxyl absorption at $3452 \mathrm{~cm}^{-1}$ (Berger et al., 1951 and Patel and Shen, 1976). Electron impact mass spectrum of the compound (Fig. S3) failed to give the molecular ion peak, but showed peak at $\mathrm{m} / \mathrm{e} 572\left(\mathrm{M}^{+}-\mathrm{H}_{2} \mathrm{O}\right)$, and also the characteristic fragmentation peaks corresponding to lasalocid A. McLafferty rearrangement following cleavage at $\mathrm{C}_{11}-\mathrm{C}_{12}$ and the subsequent loss of tetrahydropyranyl ring yielded the prominent peak at $\mathrm{m} / \mathrm{e} 211$, which on further rearrangement yielded the peak at $\mathrm{m} / \mathrm{e} 155$. The base peak at $\mathrm{m} / \mathrm{e} 57$ results by the $\alpha$-fission at carbonyl group. Other characteristic fragmentation peaks were also as reported for the pyrolytic cleavage for lasalocid A (Westley, 1974). The ${ }^{13} \mathrm{C}$ NMR spectrum of the compound (Fig. S4) in $\mathrm{CDCl}_{3}$ (TMS as internal standard) along with the offresonance spectrum clearly indicated the presence of 34 carbon atoms, belonging to 8 methyls, 8 methylenes, 4 oxymethines, 6 methines, and 8 quarternary carbons including a carboxylate and a ketone. The complete assignment of the ${ }^{13} \mathrm{C}$ NMR spectra of the compound was carried out by comparison with the published ${ }^{13} \mathrm{C}$ data for lasalocid $\mathrm{A}$ and shown in Table S1 (Seto et al., 1978). The numbering system for the compound follows Westley (1976). The genus Streptomyces generally produce polyether antibiotics, characterized by several cyclic ether systems, a single carboxylic acid function at one end of the molecule and the prevalence of C-alkyl groups (Westley, 1976, 1981).

The numbering system for the compound follows Westley (1976). The genus Streptomyces generally produce polyether antibiotics, characterized by severa cyclic ether systems, a single carboxylic acid function at one end of the molecule and the prevalence of C-alkyl groups (Westley, 1976, 1977).

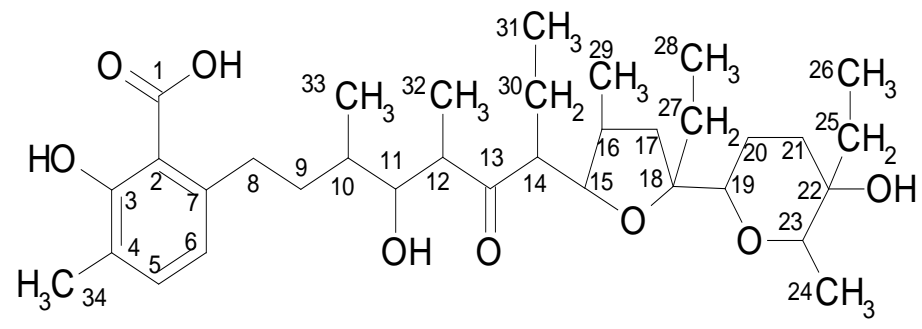

Lasalocid A

Figure 4 The predicted structure of compound TBGA-1 based on spectral analysis

The purified compound TBGA-1 is active in vitro primarily against grampositive bacteria (Table-2). However it shows activity against some of the gramnegative bacteria like E. coli, P. fluorescens and S. typhi and also against nonfilamentous fungi like $C$. albicans. In addition to major antibiotics such as streptomycin, produced by $S$. griseus, it has also been reported to produce many other antibiotics (Iwamoto et al., 1990; Larsen et al., 1988, Larsen et al., 1989) This is the first report on the production of lasalocid A, a polyether ionophore complex antibiotic from a strain of S. griseus. However, another polyether ionophore compound, 16-Deethylindanomycin (A83094A) was reported earlier (Larsen et al., 1988).

Table 2 Minimum Inhibitory Concentration (MIC) of purified compound against different bacterial strains and non-filamentous fungi

\begin{tabular}{llcc}
\hline Sl. No & Microorganisms & MTCC No. & MIC $(\boldsymbol{\mu g} / \mathbf{m L})$ \\
\hline A & Bacteria & 2682 & 12 \\
1 & Arthrobacter protophormiae & 430 & 3 \\
2 & Bacillus cereus & 441 & 2 \\
3 & B. subtilis & 739 & 28 \\
4 & Escherichia coli & 443 & 24 \\
5 & E. coli & 109 & 45 \\
6 & Klebsiella pneumoniae subsp. & 426 & $>100$ \\
7 & pneumoniae & 741 & $>100$ \\
8 & Proteus vulgaris & 103 & 26 \\
9 & Pseudomonas aeruginosa & 733 & 34 \\
10 & P. fluorescens & 97 & $>100$ \\
11 & Salmonella typhi & 740 & 2 \\
12 & Serratia marcescens & 737 & 3 \\
13 & Staphylococcus aureus & & \\
B & Non-filamentous fungi & 227 & 28 \\
1 & Candida albicans & 36 & $>100$ \\
2 & Saccharomyces cerevisiae & aureus & \\
\hline
\end{tabular}

MIC: minimum inhibitory concentration, MTCC No.: Accession code identifying strains held within the Microbial Type Culture Collection and Gene Bank, CSIR-IMTech, Chandigarh, India.

\section{CONCLUSION}

It can be concluded that the forest soils of Neyyar wild life sanctuary are abundant in Actinomycetes, and are rich sources of microorganisms producing potential antibiotics and other metabolites. TBG19NRA1 isolated from this area is identified as Streptomyces griseus (synonym $S$. setonii) based on morphological, physico-chemical and molecular phylogenetic analysis based on $16 \mathrm{~s}$ rDNA sequences. The antibiotic compound TBGA-1 produced by TBG19NRA1 has been identified as lasalocid A and this is the first report of lasalocid A from $S$. griseus strain.

Acknowledgments: Authors acknowledge Dr. S. Mayilraj, IMTECH Chandigarh, India for the confirmation of taxonomic identification of the strain S. Shiburaj and Jeeshma N.P. acknowledge Kerala State Council for Science Technology and Environment (KSCSTE) and Gayathri V. acknowledges Council of Scientific \& Industrial Research (CSIR), Govt of India for financial support.

\section{REFERENCES}

Anderson, A.S., Wellington, E.M. (2001). The taxonomy of Streptomyces and related genera. Int. J. Syst. Evol. Microbiol. 51, 797-814. http://dx.doi.org/10.1099/00207713-51-3-797

Atlus, R.M. and Perks, L.C (1993). Handbook of Microbiological Media, CRC Press, London.

Berger, J., Rachlin, A.I., Scott, W.E., Sternbach, L.H., Goldberg, M.W. (1951)

The isolation of three new crystalline antibiotics from Streptomyces. J. Am. Chem. Soc. 73, 5295-5298. https://doi.org/10.1021/ja01155a084 
Chakrbarti, T. (1998). Actinomycetes- Isolation, Screening, Identification and Gene cloning - Laboratory manual, IMTECH, Chandigarh, India.

Clerc, I.T., Pretsch, E. and Seibl, J. (1981). Structural analysis of organic compounds by combined application of spectroscopic methods, Elsevier Scientific Publishing Co., New York.

Fair, R., and Tor, Y. (2014). Antibiotics and Bacterial Resistance in the $21^{\mathrm{s}}$ Century. Perspectives in Medicinal Chemistry, 6, 25-64. http://dx.doi.org/10.4137/PMC.S14459

Felsenstein, J. (1985). Confidence limits on phylogenies: an approach using the bootstrap. Evolution, 39, 783-791. http://dx.doi.org/10.2307/2408678

Hall, T.A. (1999). BioEdit: a user-friendly biological sequence alignment editor and analysis program for Windows 95/98/NT. Nucl. Acids. Symp. Ser., 41, 9598.

Holmalahti, J., Raatikainen, O., Wright, A., Laatsch, H., Spohr, A., Lyngberg, O.K., Nielson, J., (1998). Production of dihydroabikoviromycin by Streptomyces anulatus: Production parameters and chemical characterization of genotoxicity. $J$. Appl. Microbiol., 85, 61-68. http://dx.doi.org/10.1046/j.1365-2672.1998.00472.x

Iwamoto, T., Tsujii, E., Ezaki, M., Fujie, A., Hashimoto, S., Okuhara, M., Kohsaka, M., Imanaka, H. (1990) FR109615, a new antifungal antibiotic from Streptomyces setonii: taxonomy, fermentation, isolation, physico-chemica properties and biological activity. J. Antibiot., 43, 1-7. http://dx.doi.org/10.7164/antibiotics.43.1

Jeong S.Y., Han M.H., Jin C.Y., Kim G.Y., Choi B.T., Nam T.J., Kim S.K., Cho Y.H. (2010). Apoptosis induction of human leukemia cells by Streptomyces sp. SY-103 metabolites through activation of caspase-3 and inactivation of Akt. Int $J$ Mol Med., 25(1),31-40. http://dx.doi.org/10.3892/ijmm 00000310

Johnson, L.F. and Jankowski, W.C. (1972). Carbon-13 NMR spectra, WileyIntersciences, New York.

Jukes, T.H., Cantor, C.R. (1969) In: H.N. Munro (Ed.) Mammalian protein metabolism, Academic Press, New York, pp 21-123.

Kieser, T., Bibb, M. J., Buttner, M. J., Chater, K. F., Hopwood, D. A. (2000) Practical Streptomyces Genetics, John Innes Foundation, Norwich.

Lucas, X., Senger, C., Erxleben, A., Grüning, B. A., Döring, K., Mosch, J., Flemming, S., Günther, S. (2013). StreptomeDB: a resource for natural compounds isolated from Streptomyces species. Nucleic Acids Research, 41(Database issue). http://dx.doi.org/10.1093/nar/gks1253

Larsen, S.H., Boek, L.D., Mertz, F.P., Paschal, J.W., Occolowitz, J.L. (1988). 16Deethylindanomycin (A83094A), a novel pyrrole-ether antibiotic produced by a strain of Streptomyces setonii. Taxonomy, fermentation, isolation and characterization. J. Antibiot., 41, 1170-1177.

Larsen, S.H., Berry, D.M., Paschal, J.W., Gilliam, J.M. (1989). 5 Hydroxymethylblasticidin S and blasticidin S from Streptomyces setonii culture A83094. J. Antibiot., 42, 470-471. http://dx.doi.org/10.7164/antibiotics.42.470

Liu, Z., Shi, Y., Zhang, Y., Zhou, Z., Lu, Z., Li, W., Huang, Y., Rodrı'guez, C and Goodfellow, M (2005). Classification of Streptomyces griseus (Krainsky 1914) Waksman and Henrici 1948 and related species and the transfer of 'Microstreptospora cinerea' to the genus Streptomyces as Streptomyces yanii sp. nov, Inter J. Systematic Evolutionary Microbiol., 55, 1605-1610. http://dx.doi.org/10.1099/ijs.0.63654-0

Mandel M., Marmur, J. (1968). In: L. Grossman, K. Moldave (Eds.), Methods in Enzymology, Vol. 12, Academic Press, New York, pp. 195-206.

Mellouli, L., Ameur-Mehdi, R.B., Sioud, S., Salem, M., Bejar, S. (2003) Isolation, purification and partial characterization of antibacterial activities produced by a newly isolated Streptomyces sp. US24 strain. Res. in Microbiol. 154, 345-352. http://dx.doi.org/10.1016/S0923-2508(03)00077-9

Murray, M.G., Thompson, W.F. (1980). Rapid isolation of high molecular weight plant DNA. Nucleic Acids Res., 8, 4321-4326. http://dx.doi.org/10.1093/nar/8.19.4321

Nonomura, H. (1974). Key for classification and identification of 458 species of the Streptomyces included in ISP. J. Ferment. Technol., 52, 78-92.

Olano, C., Méndez, C., Salas, J. A. (2009). Antitumor Compounds from Marine $\begin{array}{llll}\text { Actinomycetes. } & \text { Marine } & \text { 210-248. }\end{array}$ http://dx.doi.org/10.3390/md7020210

Patel, D.J., Shen, C. (1976). Structural and kinetic studies of lasalocid A (X537A) and its silver, sodium, and barium salts in nonpolar solvents. Proc Natl Acad Sci U S A, 73(6), 1786-1790.

Patel, J. B., Wallace, R. J., Brown-Elliott, B. A., Taylor, T., Imperatrice, C., Leonard, D. G., Wilson, R. W., Mann, L., Jost, K. C., Nachamkin, I. (2004). Sequence-based identification of aerobic actinomycetes. J. Clin. Microbiol. 42(6), 2530-2540. http://dx.doi.org/10.1128/JCM.42.6.2530-2540.2004

Saitou, N., Nei, M. (1987). The neighbor-joining method: a new method for reconstructing phylogenetic trees. Mol. Biol. Evol., 4, 406-425.

Sanger F., Nicklen, S., Coulson, R. (1977). DNA sequencing with chain terminating inhibitors. Proc. Natl. Acad. Sci. USA, 74, 5463-5467.

Seto, H., Westley, J. W., Pitcher, R. G. (1978). The complete assignment of the 13C NMR spectra of lasalocid and the sodium salt-complex of the antibiotic, $J$. Antibiot., 31, 289-293. http://dx.doi.org/10.7164/antibiotics.31.289

Shirling, E.B., Gottlieb, D. (1966). Methods for characterization of Streptomyces species. Int. J. Syst. Bacteriol., 16, 313-340. http://dx.doi.org/10.1099/00207713$\underline{16-3-313}$
Shirling, E.B., Gottlieb, D. (1969). Cooperative description of type cultures of Streptomyces IV. Species descriptions from the second, third and fourth studies. Int. J. Syst. Bacteriol., 19, 391-512. http://dx.doi.org/10.1099/00207713-19-4391

Staneck, J.L. and Roberts, G.D. (1974) Simplified approach to identification of aerobic actinomycetes by thin-layer chromatography. Appl. Microbiol., 28, 226231.

Stackebrandt, E., Liesack, W., Witt, D. (1992). Ribosomal RNA and rDNA sequence analyses. Gene 115, 255-260. http://dx.doi.org/10.1016/0378 1119(92)90567-9

Kumar S., Stecher G., Li M., Knyaz C., Tamura K. (2018). MEGA X: Molecular Evolutionary Genetics Analysis across computing platforms. Molecular Biology and Evolution 35:1547-1549. https://doi.org/10.1093/molbev/msy096

Thompson, J.D., Gibson, T.J., Plewniak, F., Jeanmougin, F., Higgins, D.G (1997). The Clustal X windows interface: flexible strategies for multiple sequence alignment aided by quality analysis tools. Nucleic Acids Res., 24 4876-4882. http://dx.doi.org/10.1093/nar/25.24.4876

Waksman, S.A. (1961). The Actinomycetes Volume-2, Classification, identification, and description of genera and species, Williams and Wilkins Co. Baltimore.

Weisburg, W.G., Barns, S.M., Pelletier, D.A., Lane, D.J. (1991). 16S ribosomal DNA amplification for phylogenetic study. J. Bacteriol., 173, 697-703.

Westley, J. W., Benz, W., Donahue, J., Evans, R. H., Jr., Scott, C. G., Stempel, A., \& Berger, J. (1974). Biosynthesis of lasalocid. III. Isolation and structure determination of four homologs of lasalocid A. J. Antibiot. (Tokyo), 27(10), 744753. https://doi.org/10.7164/antibiotics.27.744

Westley, J. W. (1976). A proposed numbering system for polyether antibiotics. $J$. Antibiot. (Tokyo), 29(5), 584-586. https://doi.org/10.7164/antibiotics.29.584

Westley, J. W. (1977). Polyether antibiotics: versatile carboxylic acid ionophores produced by Streptomyces. Adv. Appl. Microbiol., 22, 177-223. https://doi.org/10.1016/S0065-2164(08)70163-1

Westley J.W. (1981) Polyether Antibiotics- Biosynthesis. In: Corcoran J.W. (eds) Biosynthesis. Antibiotics, Volume- 4. Springer, Berlin, Heidelberg.

Williams, S.T., Sharpe, M.E. (1989). Bergey's Manual of Systematic Bacteriology, Volume- 4, Williams and Wilkins Co., Baltimore.

Yoshimoto Y., Sawa T., Kinoshita N., Homma Y., Hamada M., Takeuchi T., Imoto M. (2000). MK800-62F1, a new inhibitor of apoptotic cell death, from Streptomyces diastatochromogenes MK800-62F1. I. Taxonomy, fermentation, isolation, physico-chemical properties and biological activity. $J$ Antibiot. (Tokyo), 53(6),569-74. http://dx.doi.org/10.7164/antibiotics.53.569 


\section{Supplementary Data}

Table S1. ${ }^{13} \mathrm{C}$ NMR data of lasalocid A

\begin{tabular}{|c|c|c|c|c|c|c|c|}
\hline $\begin{array}{l}\text { Carbon } \\
\text { number }\end{array}$ & Multiplicity* & ${ }^{13} \mathrm{C}$ shift (ppm) & ${ }^{13} \mathrm{C}$ shift lit* & $\begin{array}{l}\text { Carbon } \\
\text { number }\end{array}$ & Multiplicity & ${ }^{13} \mathrm{C}$ shift (ppm) & ${ }^{13} \mathrm{C}$ shift lit* \\
\hline 1 & $\mathrm{~s}$ & 173.2 & 173.6 & 18 & $\mathrm{~s}$ & 86.2 & 86.7 \\
\hline 2 & $\mathrm{~s}$ & 110.9 & 111.2 & 19 & $\mathrm{~d}$ & 70.5 & 70.9 \\
\hline 3 & $\mathrm{~s}$ & 161.6 & 161.6 & 20 & $\mathrm{t}$ & 19.5 & 20.0 \\
\hline 4 & $\mathrm{~s}$ & 123.9 & 124.1 & 21 & $\mathrm{t}$ & 29.7 & 30.2 \\
\hline 5 & $\mathrm{~d}$ & 134.8 & 135.1 & 22 & $\mathrm{~s}$ & 72.3 & 72.4 \\
\hline 6 & $\mathrm{~d}$ & 121.2 & 121.6 & 23 & $\mathrm{~d}$ & 75.9 & 76.6 \\
\hline 7 & $\mathrm{~s}$ & 144.0 & 144.4 & 24 & $q$ & 13.7 & 14.0 \\
\hline 8 & $\mathrm{t}$ & 34.3 & 34.8 & 25 & $\mathrm{t}$ & 30.3 & 30.7 \\
\hline 9 & $\mathrm{t}$ & 36.6 & 37.0 & 26 & $q$ & 6.2 & 6.6 \\
\hline 10 & $\mathrm{~d}$ & 34.5 & 34.9 & 27 & $\mathrm{t}$ & 30.2 & 30.6 \\
\hline 11 & $\mathrm{~d}$ & 72.2 & 72.8 & 28 & $q$ & 8.9 & 9.2 \\
\hline 12 & $\mathrm{~d}$ & 48.7 & 48.9 & 29 & $\mathrm{q}$ & 15.7 & 15.9 \\
\hline 13 & $\mathrm{~s}$ & 214.6 & 214.1 & 30 & $\mathrm{t}$ & 16.4 & 16.7 \\
\hline 14 & $\mathrm{~d}$ & 55.1 & 55.4 & 31 & $q$ & 12.6 & 12.9 \\
\hline 15 & $\mathrm{~d}$ & 83.6 & 84.2 & 32 & $q$ & 12.9 & 13.2 \\
\hline 16 & $\mathrm{~d}$ & 34.5 & 34.8 & 33 & $q$ & 13.1 & 13.4 \\
\hline 17 & $\mathrm{t}$ & 38.4 & 38.7 & 34 & $\mathrm{q}$ & 15.5 & 15.7 \\
\hline
\end{tabular}

*Multiplicity as indicated from off-resonance spectrum ( $\mathrm{s}=$ singlet, $\mathrm{d}=\mathrm{d}$ doublet, $\mathrm{t}=$ triplet, $\mathrm{q}=$ quartet); * Seto et al., 1978

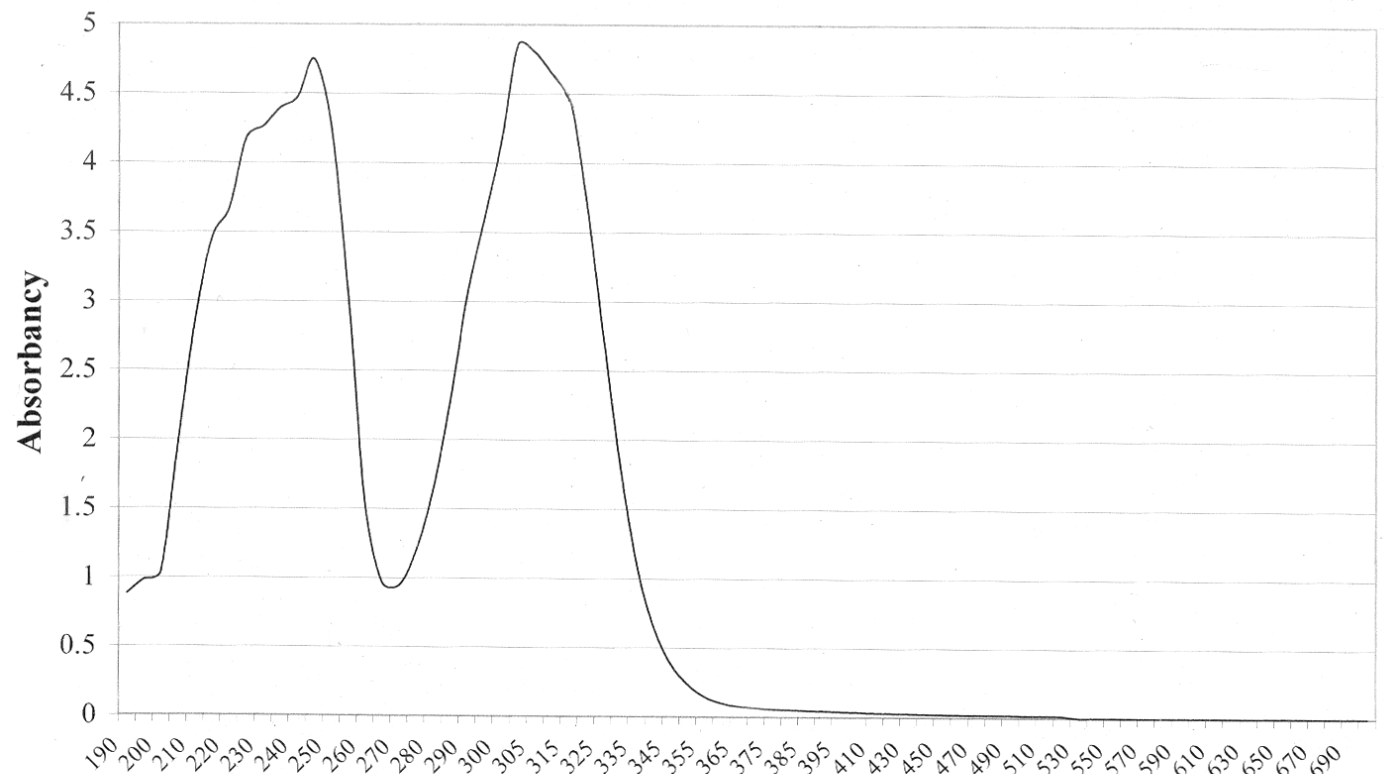

Wavelength $(\mathrm{nm})$

Fig.S1. UV spectrum of lasalocid A in $\mathrm{MeOH}$

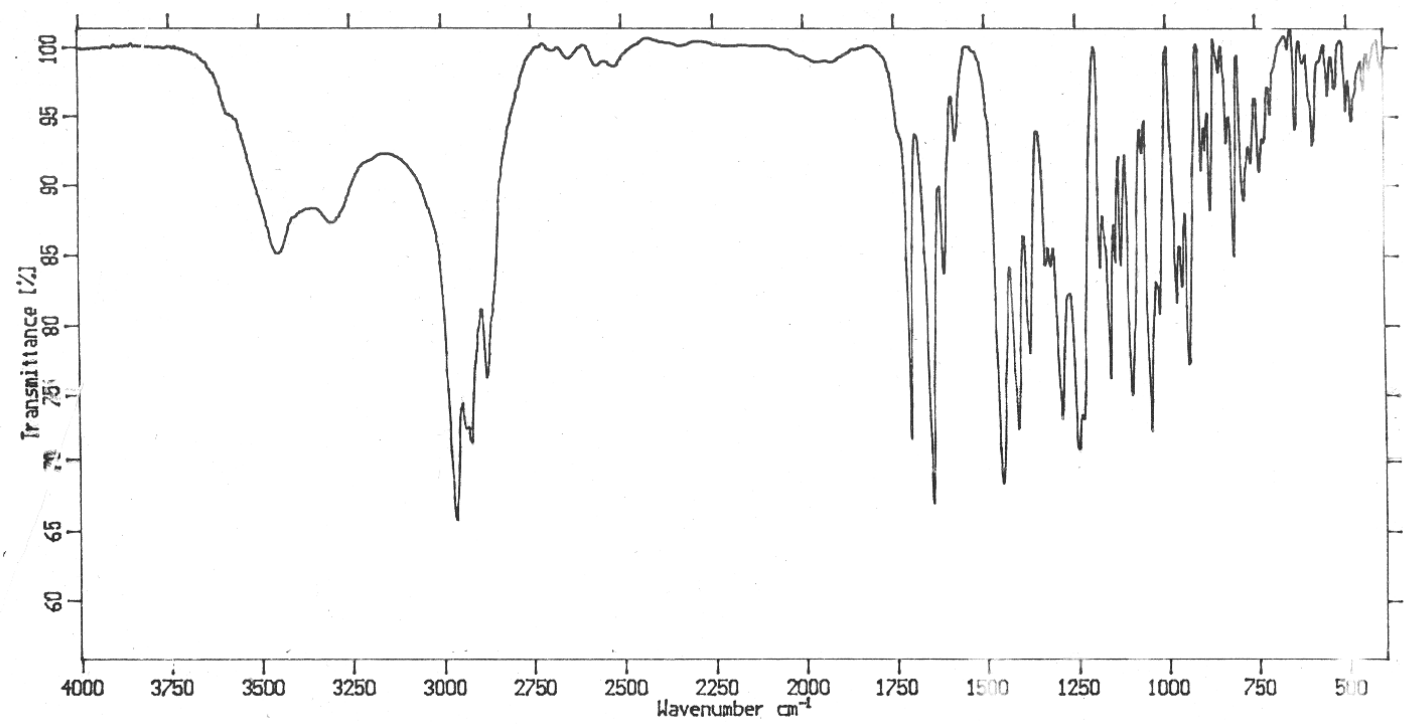

Fig. S2. IR spectrum of lasalocid A (KBr) 


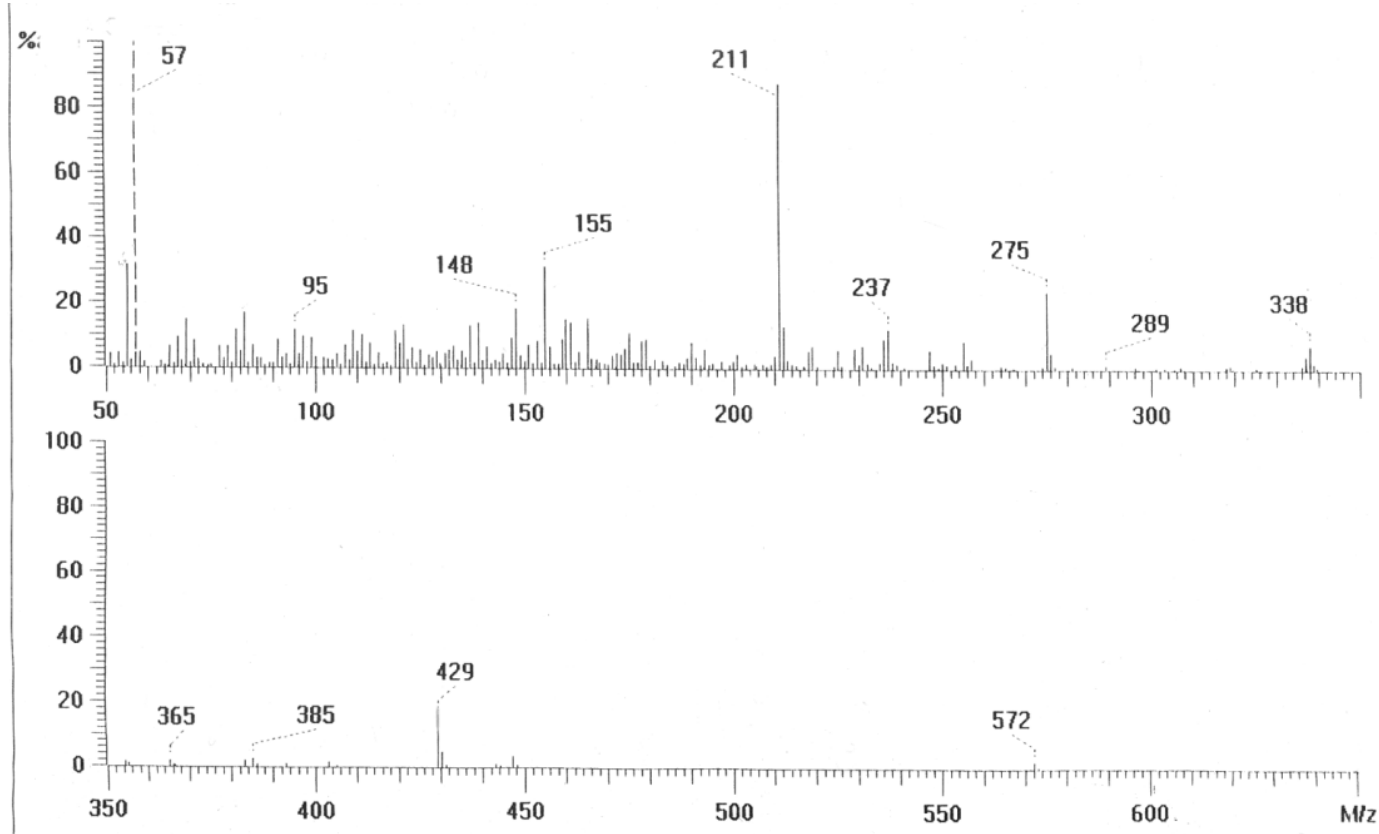

Fig. S3. Mass spectrum (EI) of lasalocid A

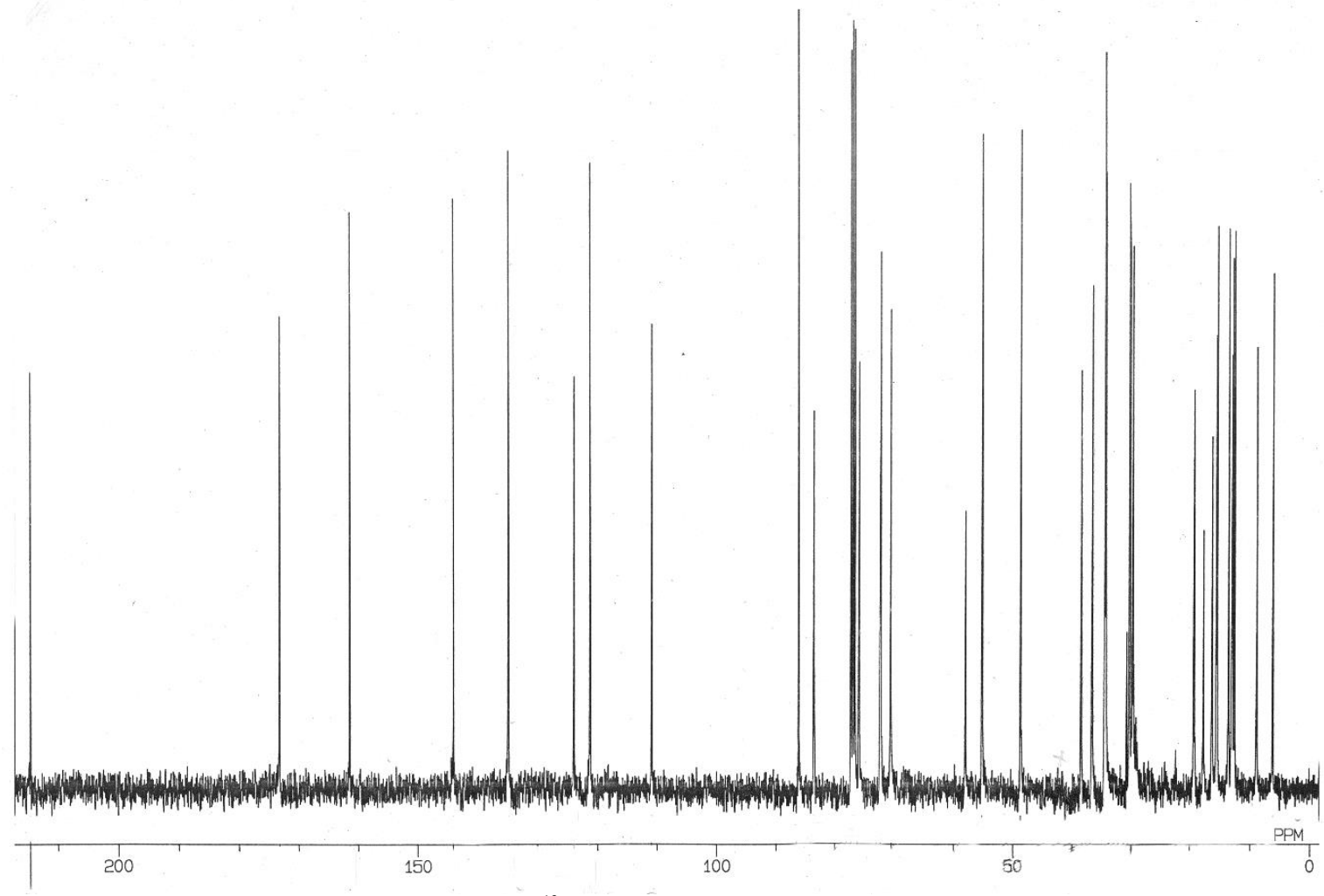

Fig. S4. ${ }^{13} \mathrm{C}$ NMR spectrum of lasalocid A 

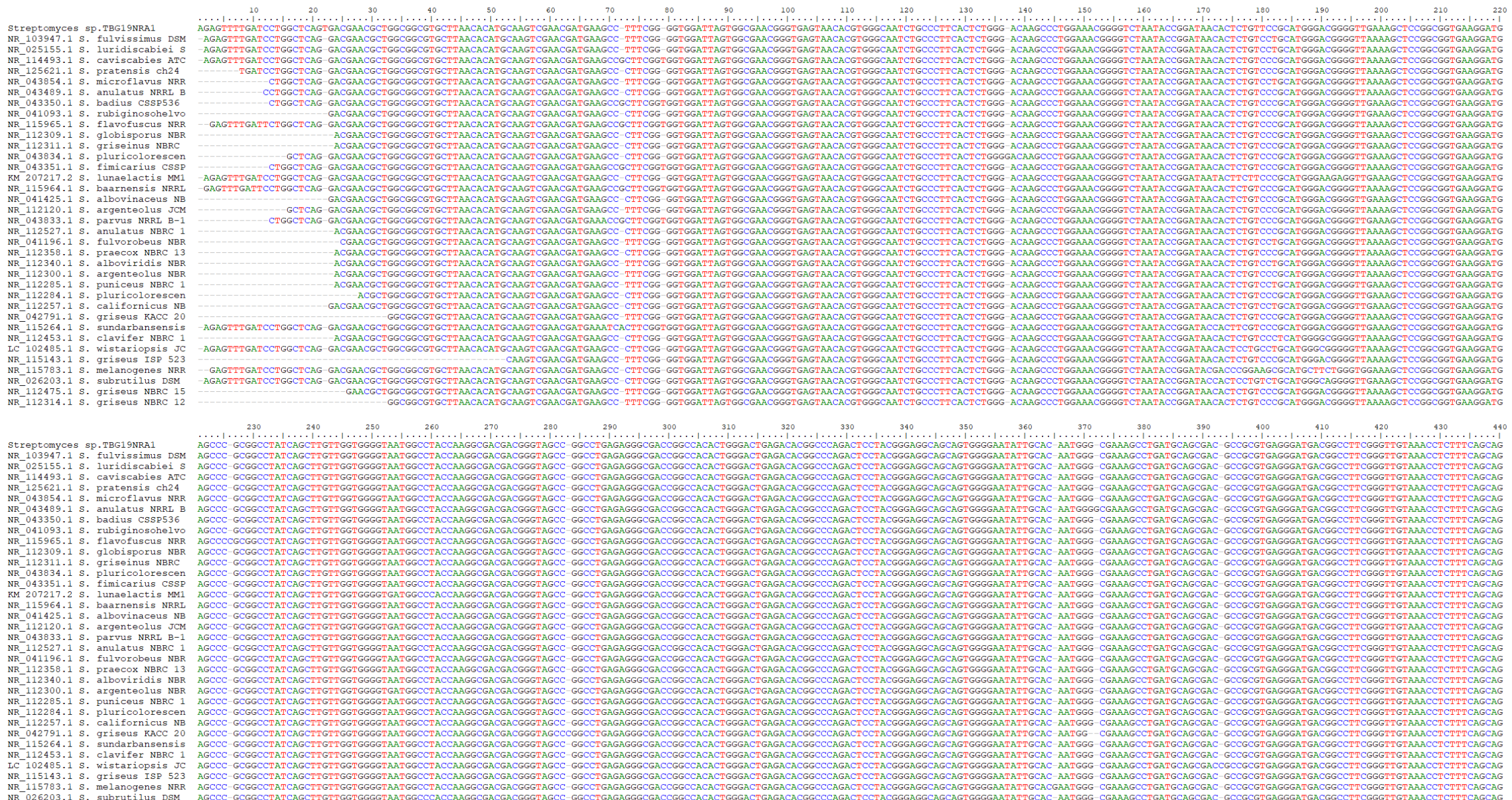

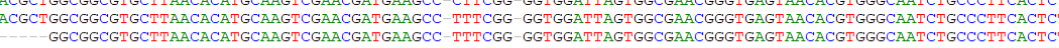
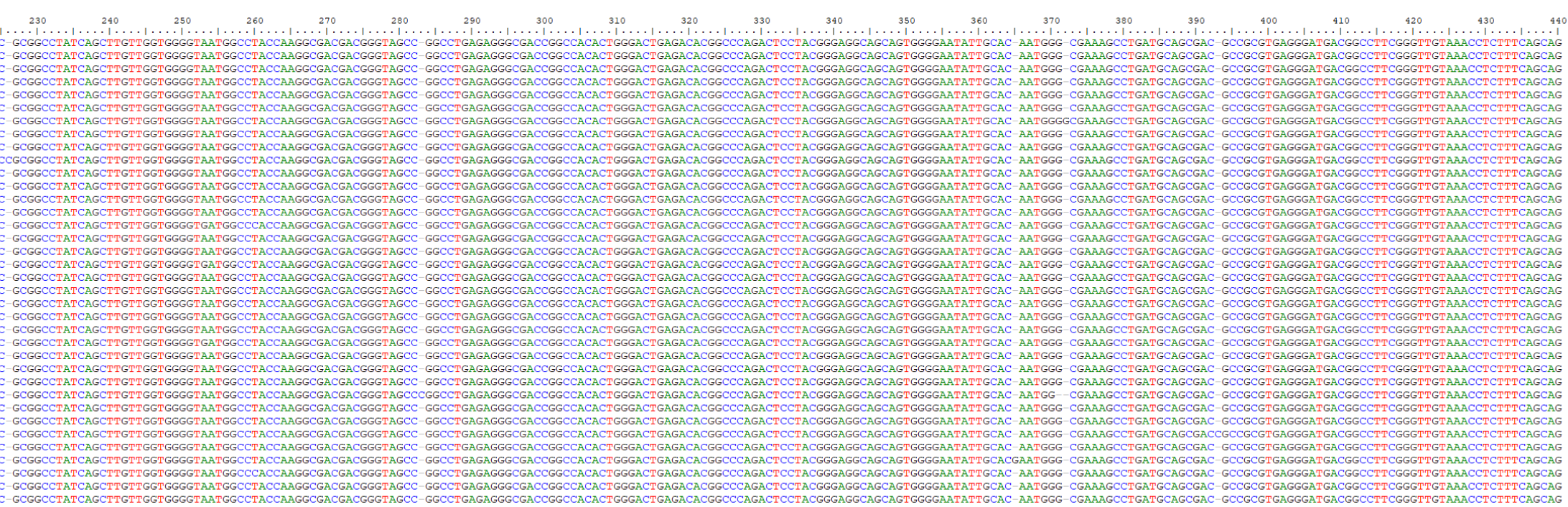


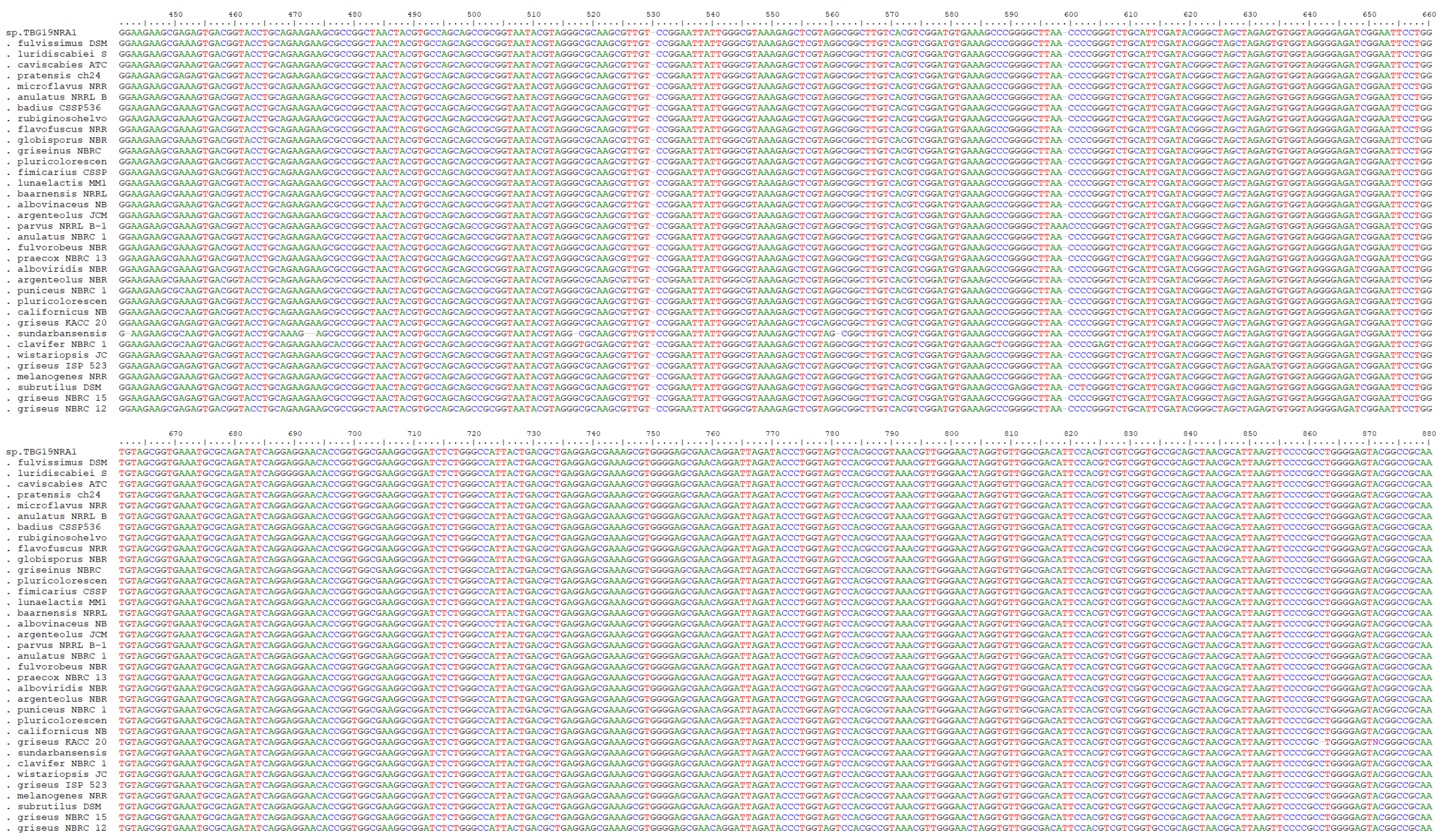



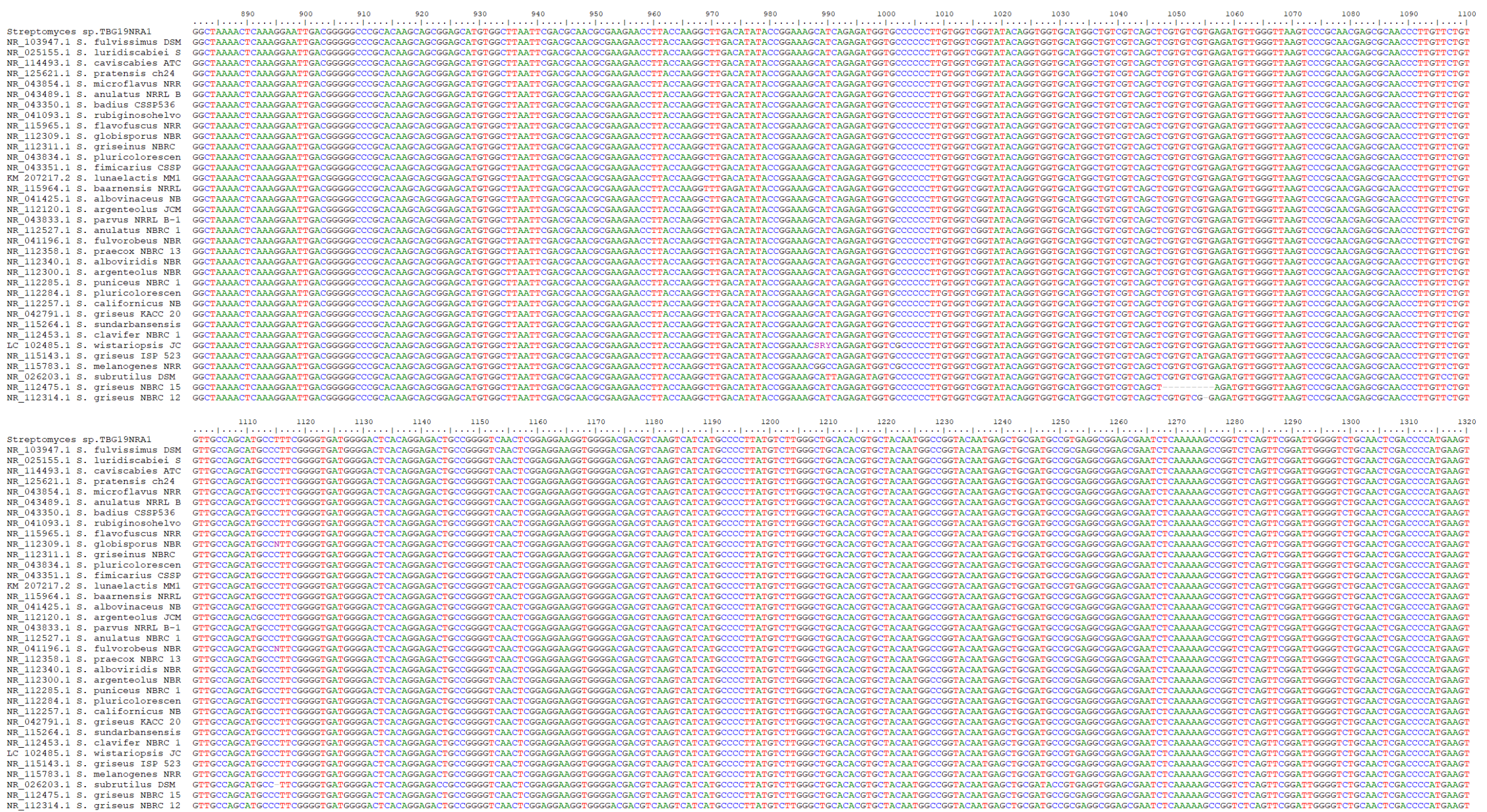

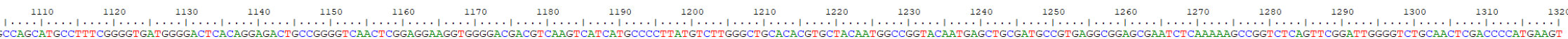

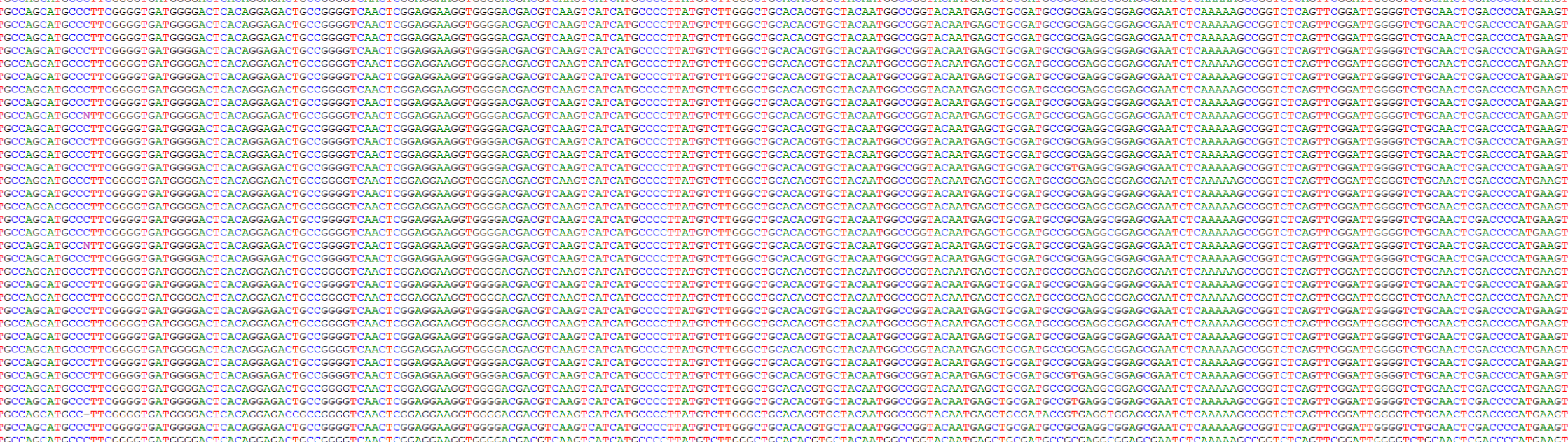



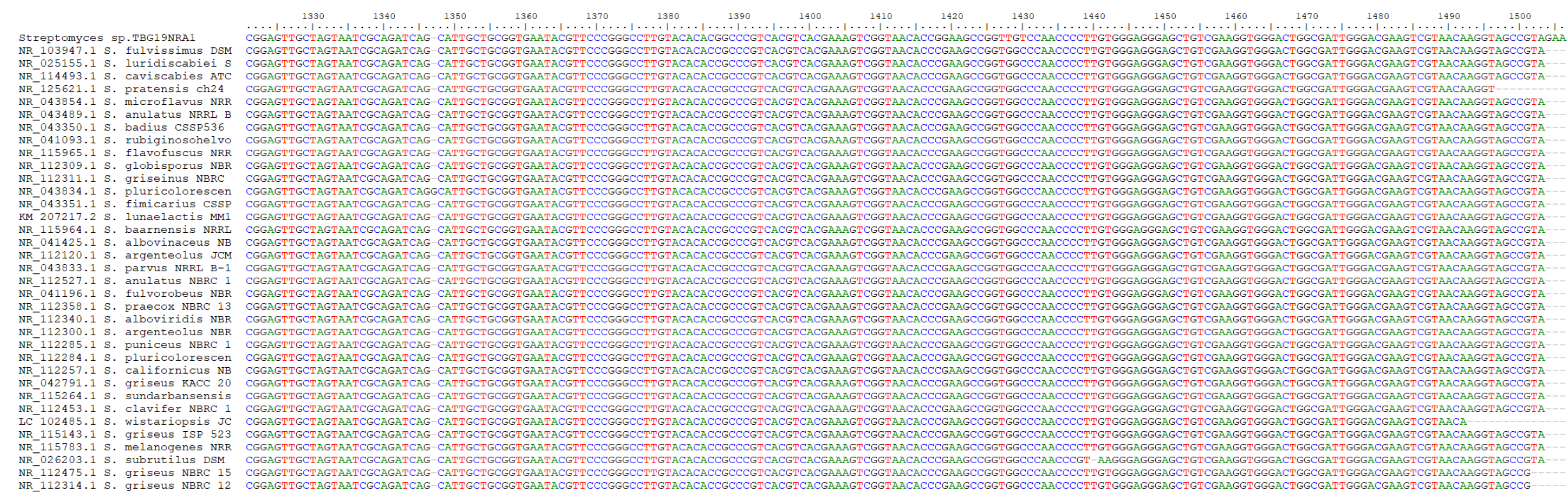

Fig. S5: Clustal W Alignment of closely related species of TBG19NRA1 after BLAST analysis 